DOI: 10.17516/1997-1370-0506

УДК 519.257:343.162.1

\title{
Investigation and the Level of Its Independence
}

\author{
Sergei A. Bochkarev* \\ Institute of State and Law Russian Academy of Sciences \\ Moscow, Russian Federation
}

Received 03.09.2019, received in revised form 31.10.2019, accepted 07.01.2020

\begin{abstract}
The article presents the results of the scientific study "The State of the Domestic Justice System: An Inside Look at Its Self-Sufficiency and Independence". The state of the problem of self-sufficiency and independence in the sociological group of investigators is studied. The statistical criterion has been used to identify paired relationships between the questionnaire answers, and Pearson fitting criterion or the $\chi^{2}$ (X squared) criterion has been used to analyze qualitative data. It is concluded that the existing guarantees of self-sufficiency and independence of investigators fail to function, and subordinate relations dominate in practice. This happens due to the existing level of senior management interference in the procedural activities of subordinate employees, which complicates the process of objective consideration (investigation) of cases and the adoption of legal procedural decisions on them.

Unlike investigators, most heads of investigative bodies understand the problem of self-sufficiency and independence as a contradiction to external threats. Therefore, they primarily try to neutralise them, not paying attention to the intrasystem threats, which are fundamental for investigators.
\end{abstract}

Keywords: investigator, head of investigative body, independence, administrative influence, organizational structure of investigative bodies.

The study was supported by the Russian Federal Property Fund, scientific project No. 18011-01232.

Research area: criminal proceedings.

Citation: Bochkarev, S.A. (2020). Investigation and the level of its independence. J. Sib. Fed. Univ. Humanit. Soc. Sci., 13(1), 27-41. DOI: 10.17516/1997-1370-0506

(C) Siberian Federal University. All rights reserved

* Corresponding author E-mail address: igpran@igpran.ru 


\section{Introduction}

Scientific team led by the author, within the frames of a research supported by the RFPF grant "The State of the Domestic Justice System: An Inside Look at Its Self-Sufficiency and Independence" conducted a largescale survey of the employees of the Russian judicial system: judges, prosecutors and investigators.

\section{Methods}

The survey "Independence (Self-Sufficiency) of Judges, Prosecutors and Investigators" consisting of 20 questions with multiple answers (from 4 to 7) was developed for the study. 19 questions were closed-ended (combined) and 1 question was open-ended. The answers to the questions in the questionnaires give the respondents an opportunity to fully and adequately express their opinion and, if it is necessary, to express a different position in an open response "other". This approach made it possible for the interviewees to express their personal vision of the problem, which reflects the focus of the study on identifying the intrasystemic attitude to the problem of independence. For the convenience of the results description, the survey questions are divided into several groups:

Questions 1-6 are general ones (position, specialisation, age, length of service, etc.) that give an opportunity to understand the composition of the respondents, their sociological characteristics and regional affiliation.

Questions 7-11, 17, and 19-20 are aimed at identifying the presence and characteristics of the problem of independence (self-sufficiency), its essence and the rate of expansion in modern Russian society.

Questions 12-15 make it possible to assess the degree of various factors' influence on independence. These factors include public opinion, the point of view of the mass media, the opinions of officials and state power bodies of federal, regional and local levels, as well as opinions of the managers-respondents.

Questions 16 and 18 give respondents on opportunity to express their attitude to the problem under study, as well as to offer the most effective ways to increase the level of in- dependence (self-sufficiency) from their point of view.

The answers to the research questions were obtained by the method of completing the questionnaires by the respondents. Questionnaires were distributed to employees at their workplace, and completed questionnaires were returned without signatures and other identifying information. The questionnaires were completed in the period from January to December 2018. Over 1200 respondents (judges, prosecutors, and investigators) were interviewed within the frames of the sociological study.

\section{General assessment}

\section{of the sociological study results}

To determine the disposition of the category "Independence" that exists in the legal consciousness of the interviewed employees, questionnaires included a question about the content of the concept of "Independence of an investigator, prosecutor and judge" (Question 20). Answers to the question were distributed as follows (Fig. 1):

The results demonstrate that the most frequent answer $(34.2 \%)$ is understanding independence as an absence of any external influence. $27.6 \%$ associate independence with the possibility to apply the law, assess the circumstances of a case and make procedural decisions at their own discretion; $25.5 \%$ with the absence of negative consequences for disagreeing with the position of senior management. 8.6\% understand independence as impossibility for anyone, including a manager, to give instructions on a case or interfere in the process of its investigation. Only $1 \%$ understand independence as absence of any supervision on investigators, prosecutors and judges, and 3.1\% gave other answers. These answers, as is evident, are not mutually exclusive, since many respondents gave several answers. They reflect an emphasis on the components of independence which a law enforcer lacks. Generally speaking, these answers reflect the universal understanding of independence as personal independence and lack of subordination.

The next key question in the questionnaire was the question on the existence of the problem of independence (self-sufficiency) of 


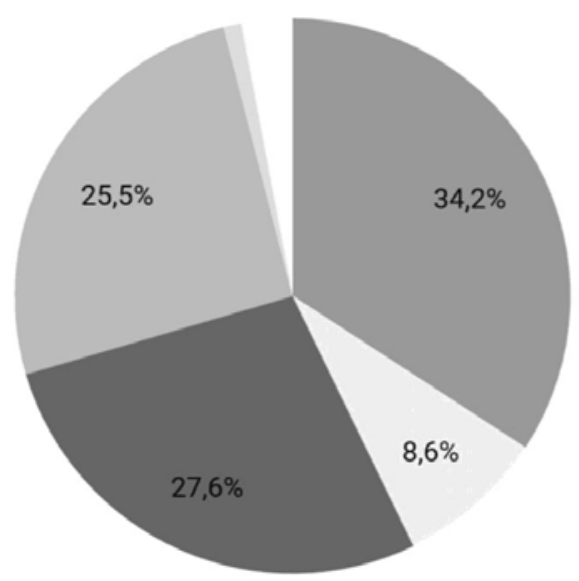

absence of any external influence

impossibility for anyone, including a manager, to give instructions on a case

or interfere in the process of its investigation

possibility to apply the law,

assess the circumstances of a case and make procedural decisions at their own discretion

absence of negative consequences for disagreeing with the position of senior management

absence of any supervision on investigators, prosecutors and judges

other

Fig. 1. The content of the concept of "Independence of an investigator, prosecutor and judge"

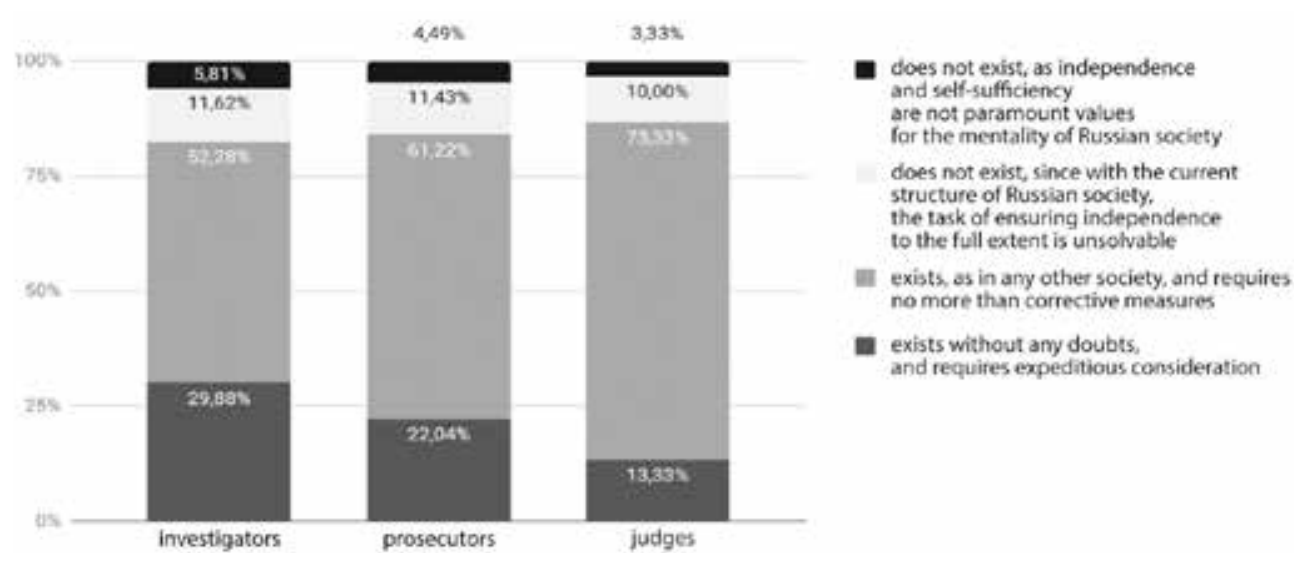

Fig. 2. Existence of the problem of independence

a judge, prosecutor and investigator in modern Russian society (Question 7). The answer options gave respondents an opportunity to express their opinion on the presence and the level of relevance of the problem under consideration. The answers were distributed as follows (see Fig. 2).

$30 \%$ of investigators, $22 \%$ of prosecutors and only $13 \%$ of judges indicated unconditional existence of the problem and necessity for its expeditious consideration. At the same time, most respondents acknowledge the problem, but are reserved on it (it exists, as in any other society, and requires no more than corrective measures): this answer is given by $73 \%$ of judges, $61 \%$ of prosecutors and $52 \%$ of investigators. The result indicates that judges are the most stable group, whereas the problem is more relevant for investigators.

The following answers were given to the question of the prevalence of the problem of independence (Fig. 3).

$33.5 \%$ of investigators, $21.5 \%$ of prosecutors and $11.5 \%$ of judges say that the problem is universal, since it is caused by the imperfection of judiciary bodies structure and organization of their activities. Therefore, investigators demonstrate the greatest concern about the problem of independence.

The general results of the statistical study indicate about the presence of the problem of independence of judges, prosecutors and investigators. All the respondents faced this problem in various forms and degrees in their profes- 
sional activities. This allowed to conclude that the problem under study exists in Russian law enforcement agencies, and therefore, it requires scientific reasoning with the subsequent suggestion of ways out of this situation.

The respondents were also asked about the main areas which primarily face the problem of independence (self-sufficiency) of judges, prosecutors and investigators (Question 9). The answers were distributed as follows (see Fig. 4).

Most respondents $(41.8 \%)$ indicated that the problem of independence resides in the administrative and organizational structure of the law enforcement system as a whole and

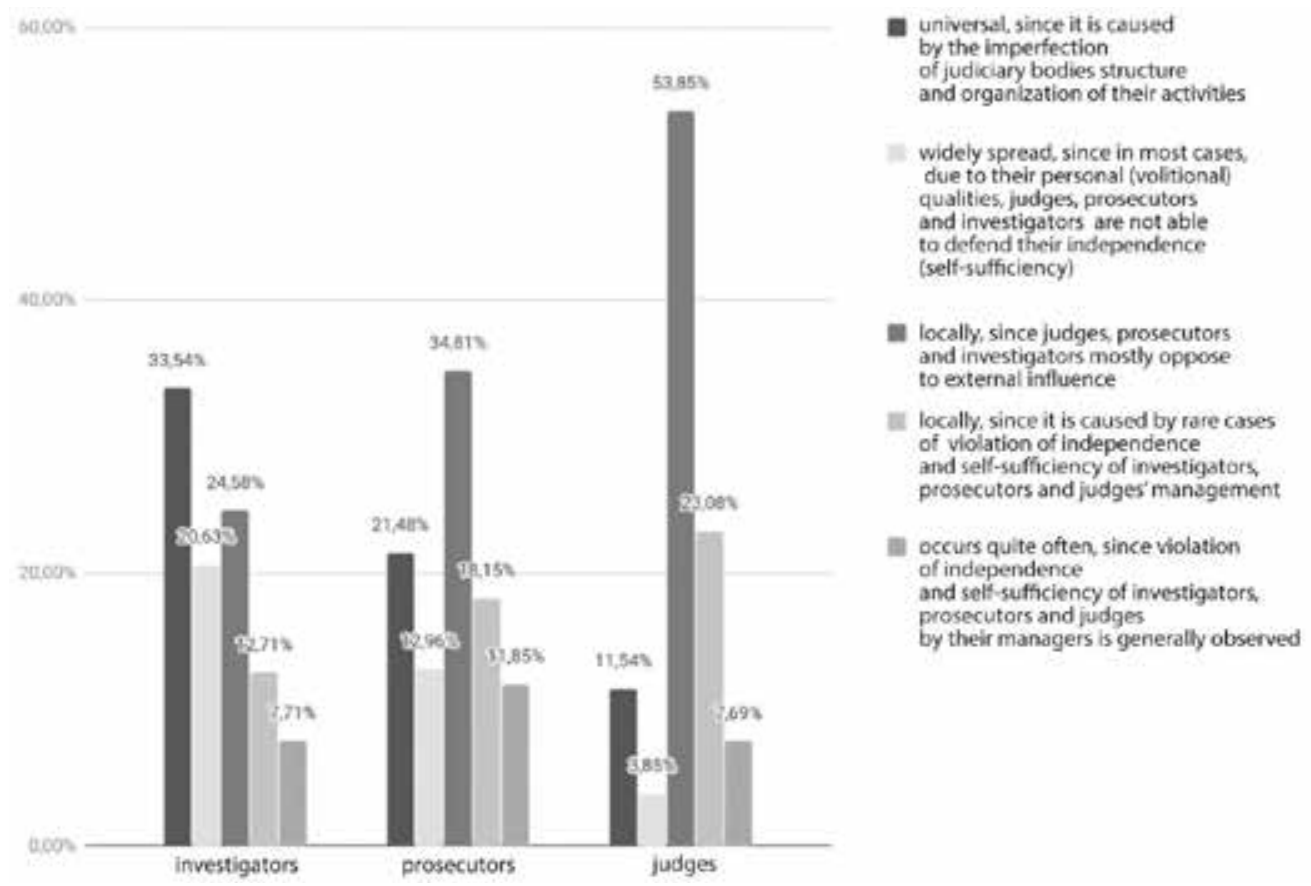

Fig. 3. Prevalence of the problem of independence (Question 8)

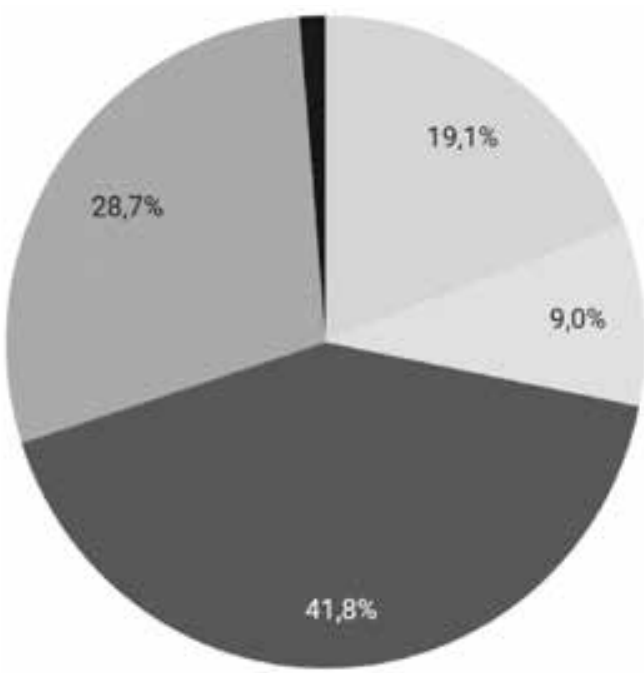

legal consciousness,

ie. personal ideas of a judge,

prosecutor and investigator

on the degree of their freedom,

self-sufficiency and independence

material and technical

security of their

professional activities

and wage rate

- administrative and organizationa structure of the law enforcement system as a whole and each

of its bodies (institutions) individually

the problem does not have common reasons, since it depends on specific cases of violating independence (self-sufficiency) of a judge, prosecutor and investigator

other

Fig. 4. The main area of the problem prevalence 
each of its bodies individually. It is to be recalled that the principle of hierarchy and subordination of lower-level employees to higher-level ones is a typical characteristic of any administrative system of state executive bodies. Thus, it is the area of administrative relations within law enforcement agencies that is most often indicated by the respondents as the cause of the problem of independence. The position of direct management, with which it is necessary to coordinate the adopted procedural decisions, and whose opinion they should focus on when making them, is a determining factor in the procedural activity of employees. Here lies the main potential danger of transferring administrative subordination to procedural one, which leads to independence levelling, since the administrative and organizational structure of the law enforcement system represents a wide scope for suppressing the will of lower-level employees. Most respondents associate the existence of the problem of independence with the administrative and organizational structure of the justice system.

The analysis of judges, prosecutors and investigators' opinions about the area where the problem of independence lies (Question 9) is presented in Fig. 5.

According to the chart, the problem of the administrative and organizational structure of the law enforcement system as a whole and each of its bodies (institutions) individually causes the greatest concern in the group of investigators (44.1\%). Prosecutors primarily note the same problem (40.4\%). As for judges, only $17.2 \%$ indicate administrative and organizational structure. Most judges indicate that the problem does not have common reasons, since it depends on specific cases of violating independence $(65.5 \%) .28 \%$ of investigators and $25.7 \%$ of prosecutors indicated that the problem does not have common reasons, that is, a much lower percentage than among judges.

The following Fig. 6 demonstrates the result of the analysis of the respondents' position on the existing level of senior management interference in the procedural activities of a judge, prosecutor and investigator.

The chart indicates that the level of senior management interference in investigators' work is high $-44.8 \%$. It is slightly lower for procuracy officers $-37.1 \%$, but the figure is significant. Judges are most protected from the threat of aninfringe on independence by their management, only $15.6 \%$ indicated that the level is high. Most judges believe that the level of interference is low (37.5\%), while this figure is three times less among investigators and prosecutors $(11.2 \%$ among investigators and $13.5 \%$ among prosecutors). Consequently, despite the guarantees of independence and

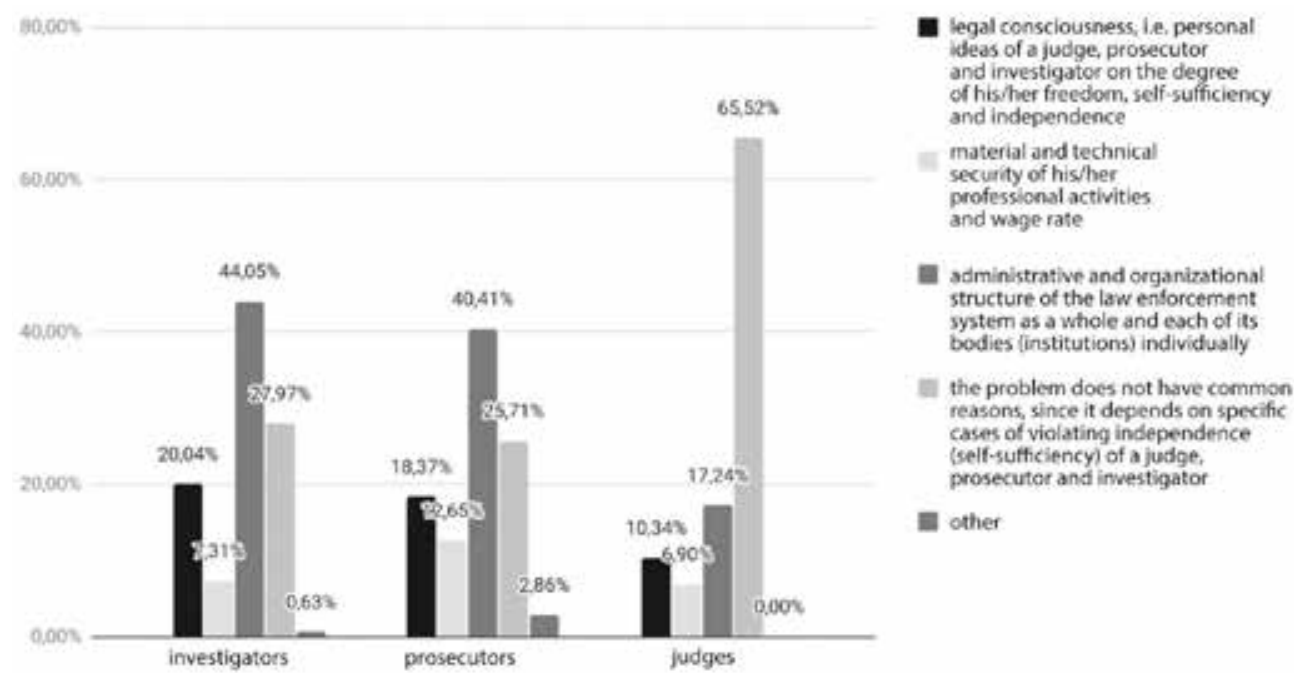

Fig. 5. The main area of the problem prevalence by groups 


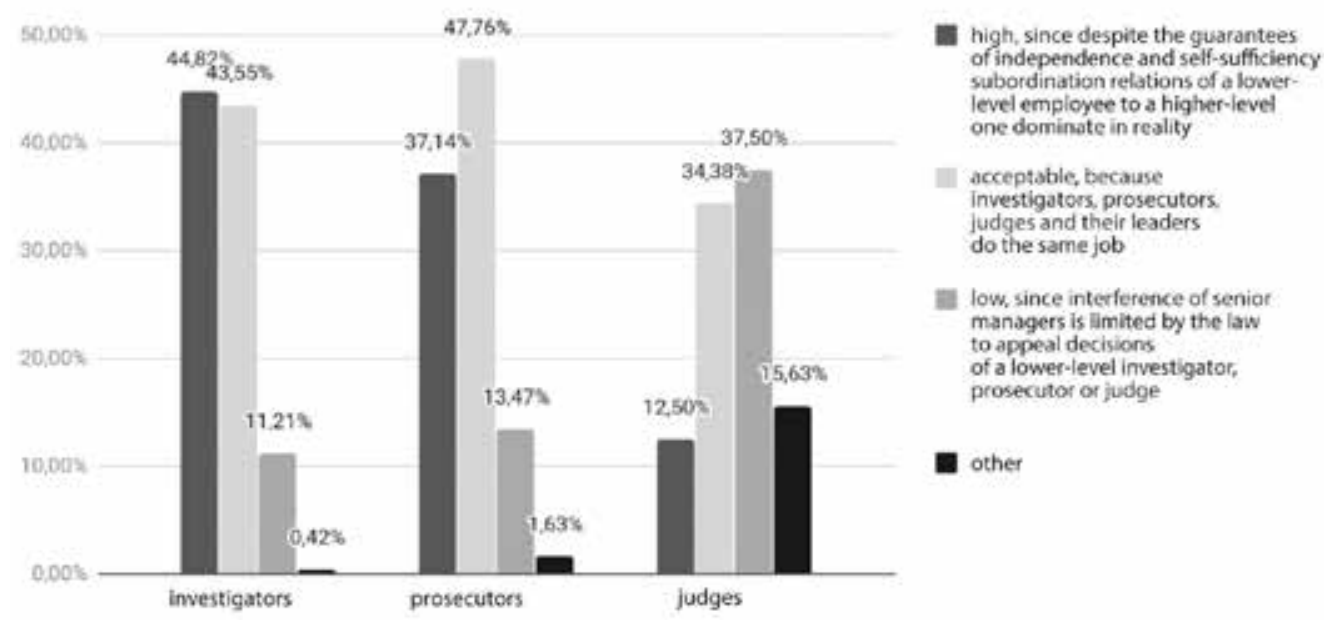

Fig. 6. The level of senior management interference in the procedural activities of a judge, prosecutor and investigator (Question 10)

self-sufficiency, subordination relations of a lower-level employee to a higher-level one dominate in the prosecution and investigative bodies in reality.

Thus, the problem primarily lies in the area of the administrative and organizational structure of the law enforcement system as a whole and of each of its bodies (institutions) individually, and is determined by the existing level of senior managers' interference in the procedural activities of a judge, prosecutor and investigator, which complicates the process of objective consideration (investigation) of cases and making legal procedural decisions on them. For this reason, the level of personal discretion in procedural activities, especially among prosecutors and investigators, is insufficient, since it can be levelled by the senior management position. As a result, these are mostly investigators who regularly encounter unacceptable, in their opinion, interference in their procedural activities from their managers. The more detailed description of the general results of the study were presented earlier (Bochkarev, 2019, 346).

\section{General characteristics}

of the reference group

As can be seen from the Fig. 7, only $10.4 \%$ of investigators are over the age of 40 , while their share among managers is $57.9 \%$. The majority of investigators (36.4\%) are between the age of 30 and 40 . More than a half of investigators $(53.8 \%)$ are in their $30 \mathrm{~s} .26 .9 \%$ of them are under the age of 25 . Most respondents in the age group over 40 are heads of investigative bodies, which should be considered in the course of further analysis.

Correlation depending on the length of service in legal profession is even more revealing. As can be seen from Fig. 8 below, most investigators $(48.7 \%)$ have up to 5 years length of service in legal profession, $24.4 \%$ from 5 to 10 years, and only $14.1 \%$ over 15 years. The heads of investigative bodies are persons with more than 15 years of service $88.9 \%$ of them.

There is a difference in the length of service in the positions held (Fig. 9).

Over a half of investigators $(50.6 \%)$ have held their positions for less than 3 years, while their percentage among managers is minimal (11.1\%). The information above indicates a significant "staff turnover" among investigators, their lack of experience and young age, which aggravates the problem with their independence and self-sufficiency.

\section{Statistical methods used}

To identify paired relationships between the answers to the questionnaire questions, a statistical criterion was used to analyse qualitative $\mathrm{X}$ squared data. By applying this criterion 


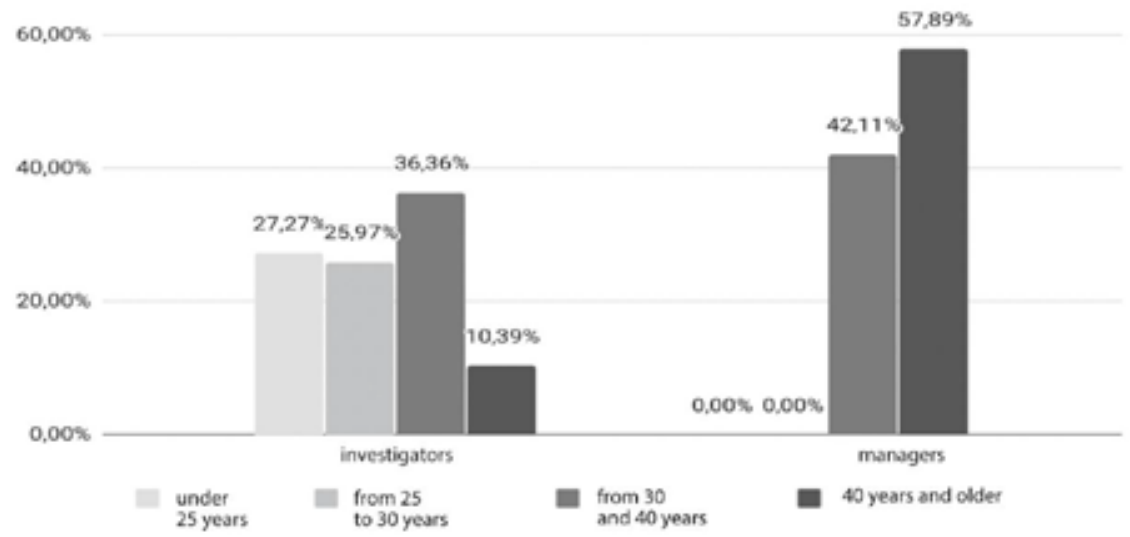

Fig. 7. The respondents' age (Question 6)

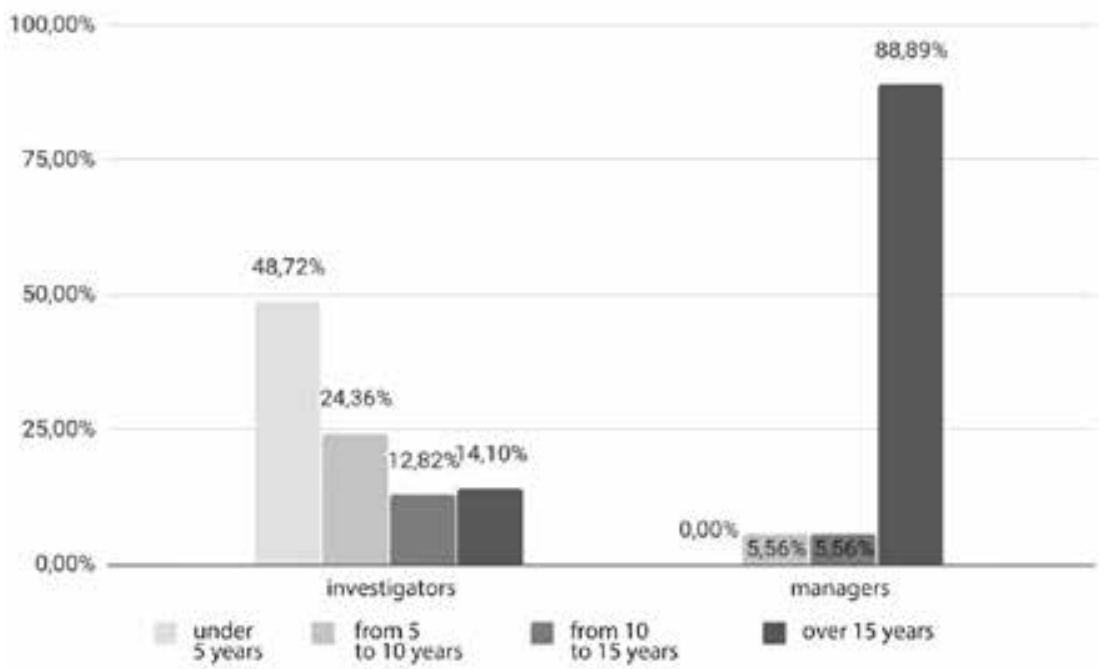

Fig. 8. Length of service in legal profession (Question 4)

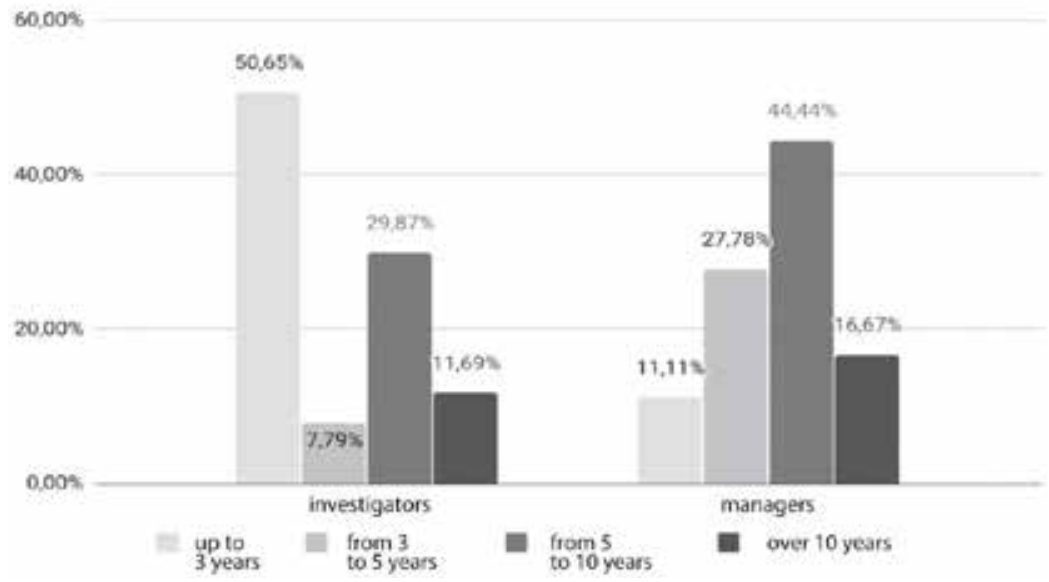

Fig. 9. Length of service in the position held (Question 5) 
to the answers to two questions, the hypothesis of the impartiality of answers to these questions (null hypothesis) was tested. Thus, interdependence of all possible pairs of the questionnaire questions was sequentially checked (about 300 pairs of questions). Pairs of both interdependent (the null hypothesis was rejected) and non-dependent (the null hypothesis was not rejected) answers to questions with a significance level of the $X$ squared criterion of $95 \%$ were identified among them. If the $\mathrm{p}$-value of the $\mathrm{X}$ squared criterion exceeded 0.95 , the answers to the questions of the selected pair are independent in more than $95 \%$ of cases, and when the $p$-value is less than 0.05 , the answers to the questions are considered dependent in 95\% cases. Analysis of the dependent pairs (where the p-value is less than 0.05) is presented below. The identified dependencies are presented in the form of bar charts. The data analysis was performed using the Python 3.7 programme, the scipy.stats package. In some cases, a significance level of $95 \%$ was not reached, but charts, nevertheless, are presented to illustrate the results obtained and provide their more detailed consideration.

\section{Analysis of statistically significant results}

The applied statistical methods have demonstrated that the assessment of the de- pendence level on senior management changes with age (Fig. 10).

As can be seen from the questionnaire survey, the level of management interference in the procedural activity is considered high by all investigators, especially at the age group from 25 to 30 years $(65 \%)$. In comparison with other age groups, the problem is least acute among young employees (under 25 ). Only $42.86 \%$ report high level of dependence, and a maximum percentage (19.05\%) comparing to other age groups indicate low level of dependence, since senior management interference is limited by the law to appeal decisions of a lower-level investigator.

An approximately similar picture is observed depending on the length of investigators' service (Fig. 11).

High level of dependence among investigators of various length of service can be also observed here. It is noteworthy that investigators with the length of service from 10 to 15 years do not note low level of interference at all. They give the maximum level (65.64\%) of responses about high level of interference.

The dependence of the frequency of unacceptable management interference on the length of service in the legal profession, taken only for investigators is also indicative in this case (Fig. 12).

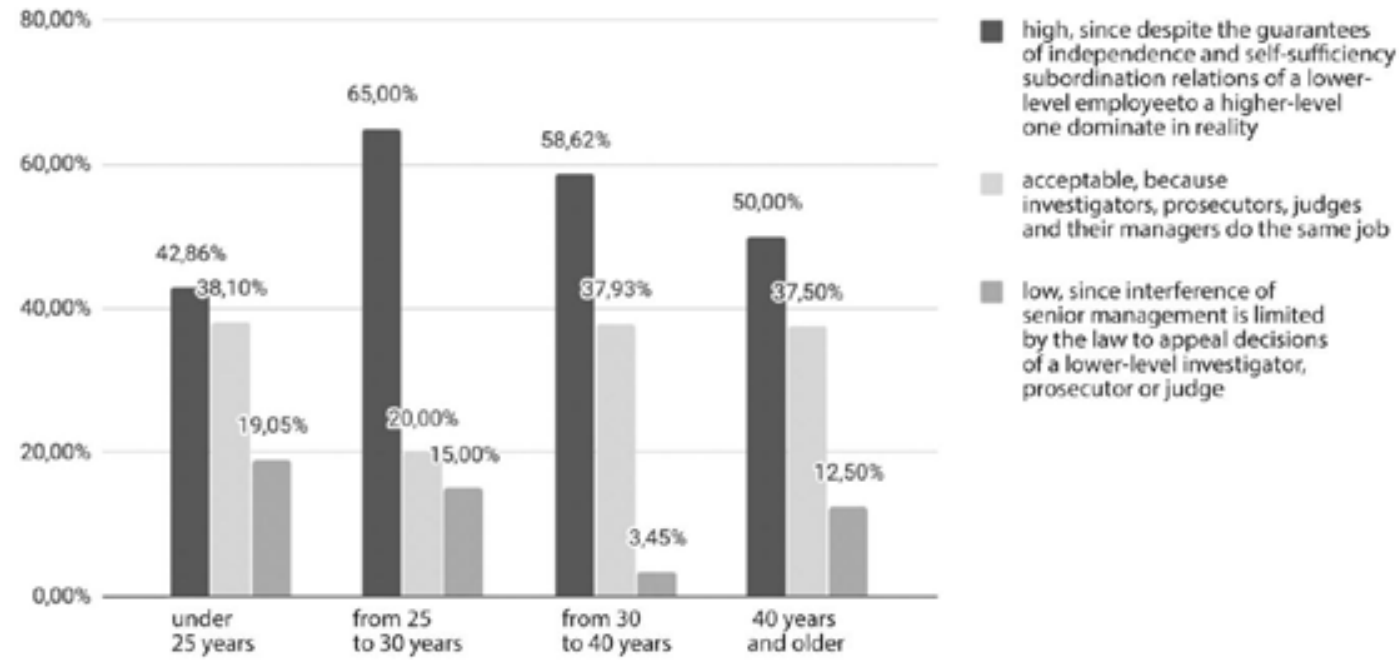

Fig. 10. Assessment of the existing level of investigators' dependence on senior management (Question 10) depending on age (Question 6), investigators only 
$80,00 \%$

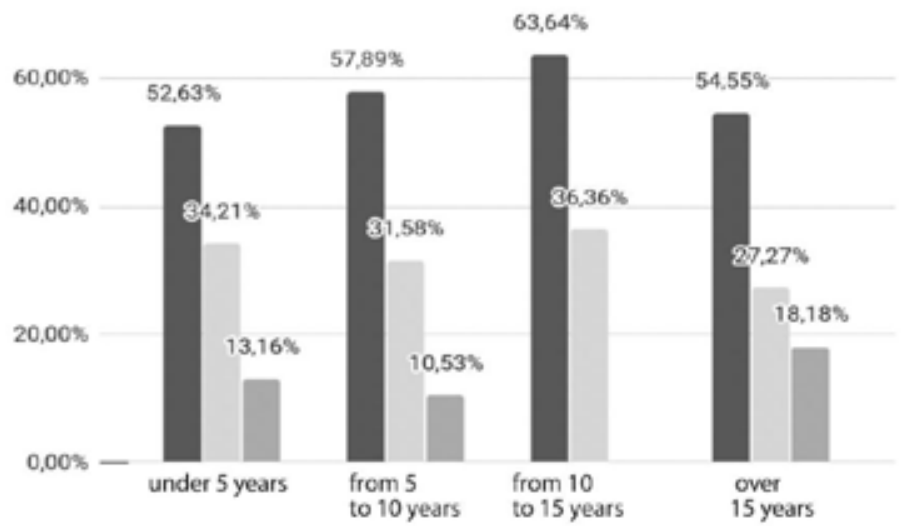

high, since despite the guarantees of independence and self-sufficiency subordination relations of a lower-level employee to a higher-level one dominate in reality

acceptable, because investigators, prosecutors, judges and their managers do the same job

low, since interference of senior management is limited by the law to appeal decisions of a lower-level investigator, prosecutor or judge

Fig. 11. The current level of senior management interference in the procedural activities of investigators (Question 10) depending on the length of service in legal profession (Question 4). Investigators only

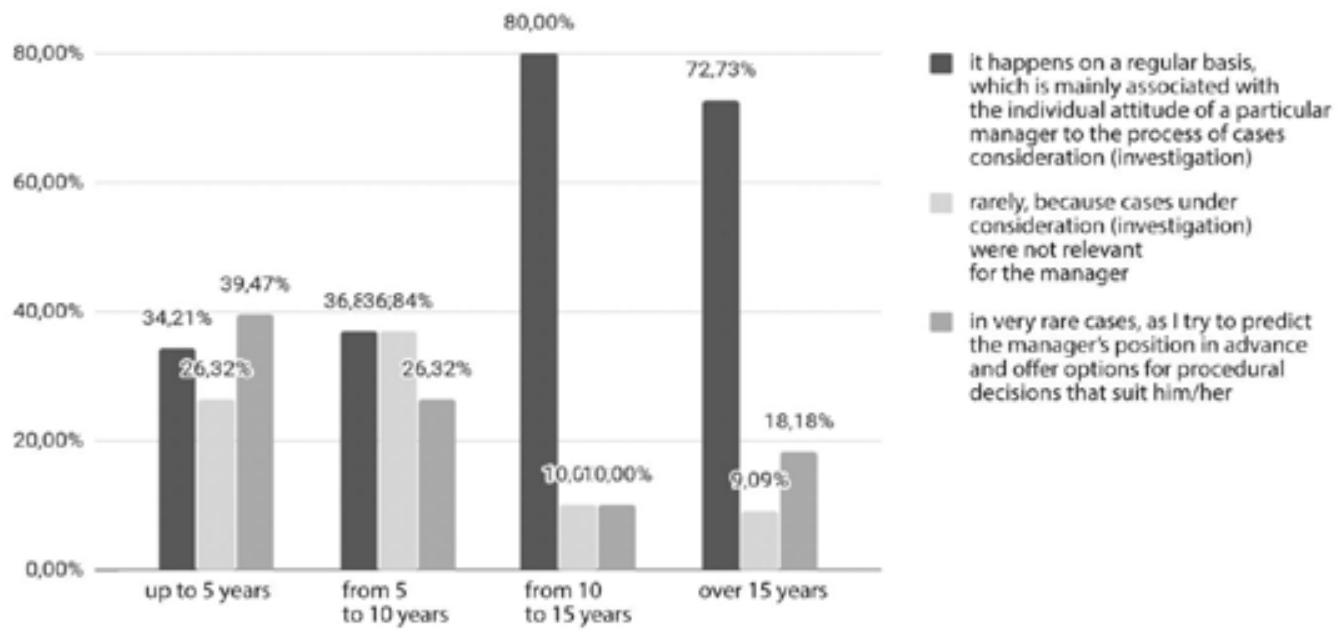

Fig. 12. Dependence of the frequency of unacceptable management interference in procedural activities (Question 19) on the length of service in the legal profession (Question 4). Investigators only

As can be seen, the number of answers indicating unacceptable management interference in procedural activity dramatically increases among the most experienced investigators with more than 10 years of service in the legal profession. It can be mainly associated with the individual attitude of a particular manager to the process of cases consideration (investigation). If for the employees with the length of service of up to 5 years and from 5 to
10 years, this indicator is $34.2 \%$ and $36.8 \%$ correspondingly, then among investigators with the length of service from 10 to 15 years $80 \%$ (72.7\% of employees with the length of service of over 15 years) of responses indicate unacceptable interference.

The next chart indicates the frequency of unacceptable management interference depending on age for the entire group of the investigation officers under study (Fig. 13). 


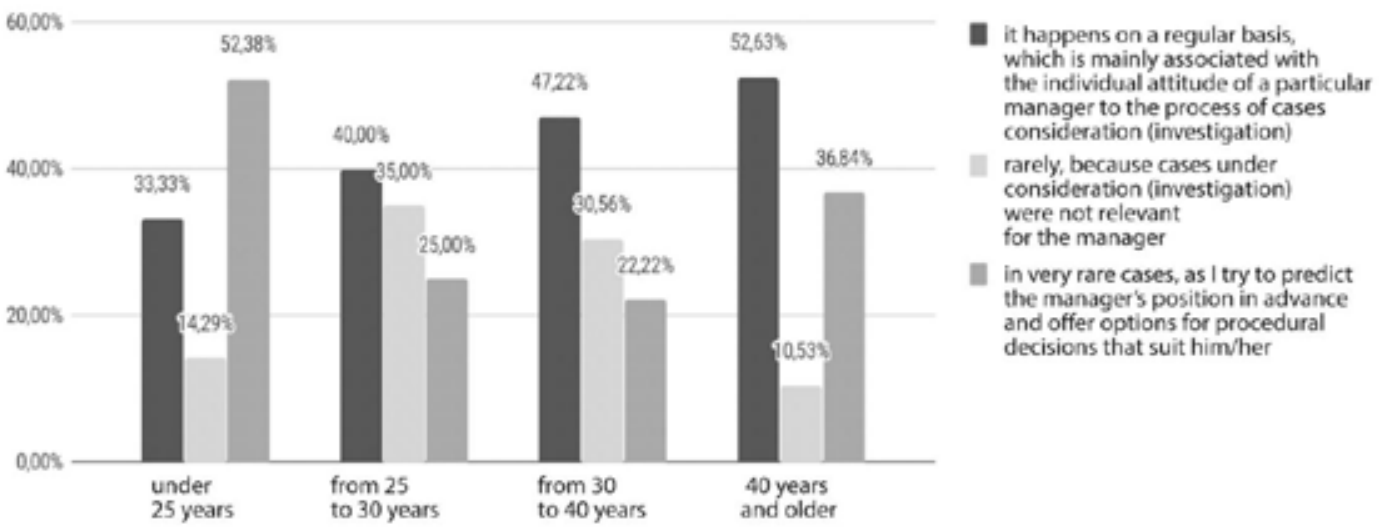

Fig. 13. Dependence of the frequency of unacceptable management interference in procedural activities (Question 19) on age (Question 6)

Results of applying statistical criterion:

The percentage of answers indicating unacceptable management interference in the process in the age groups under study gradually increases with age, which is mainly associated with the individual attitude of a particular manager to the process of cases consideration (investigation). This is the most frequently chosen option among all employees over the age of 25. Among employees at the dawn of their career (under 25$)$, more than a half $(52.38 \%)$ note that unacceptable interference takes place very rarely, as they try to predict the manager's position in advance and propose options for procedural decisions that suit their manager. But the last answer, in fact, indicates that young employees diminish their independence themselves, since they are aware which version of their action their managers might be pleased with, and act accordingly.

The results on investigators only are considered in the next Fig. 14.

\section{Results of applying statistical criterion:}

When looking at the assessments of investigators of 40 years and older, $75 \%$ of them indicate unacceptable interference. In Fig. 13 above, this figure among all employees is $52.63 \%$. It seems possible to make a conclusion that the most experienced investigators, due to their understanding and the ability to assess such an interference as unacceptable, face it most frequently.
As can be seen from Fig. 12-15, employees under 25 less commonly recognize unacceptable management interference in their professional activities. There are two possible reasons for this. There is really less interference (young investigators, for instance, are given simple cases where it is not necessary to interfere), or at this age investigators still cannot distinguish interference, mentoring (a part of studying) and ordinary administrative subordination.

Another statistically significant grouping indicator after age is an investigative officer's position. The answers of investigators and heads of investigative bodies significantly differ from each other (Fig. 15).

Most investigators $(55.7 \%)$ consider the level of interference to be high, since, despite the guarantees of independence and self-sufficiency, subordination relations of a lower-level employee to a higher-level one dominate in reality. $32.9 \%$ of investigators consider it acceptable. The managers have a different vision, most often $(45 \%)$ they indicate an acceptable level of interference, and only $35 \%$ say that this level is high. $11.4 \%$ of investigators and $20 \%$ of managers indicate low level of interference, since senior management interference is limited by the law to appeal decisions. In general, the problem is not so acute among managers.

Fig. 16 shows the position of investigators and heads of investigative bodies regarding the level of dependence on senior management. 


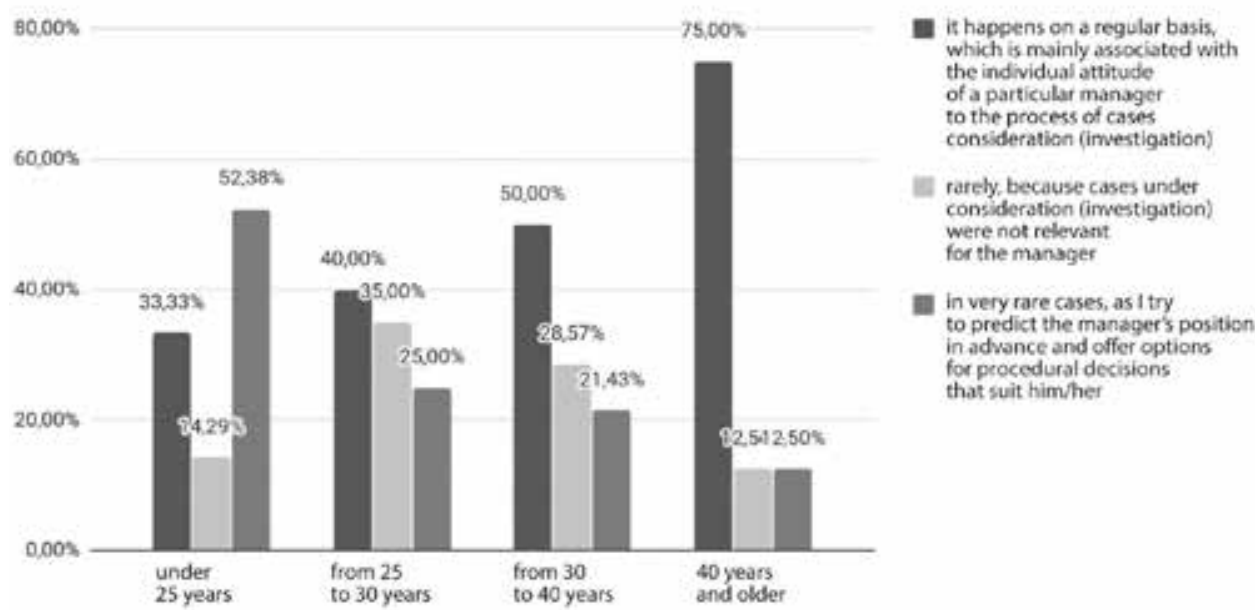

Fig. 14. Dependence of the frequency of unacceptable management interference in procedural activities (Question 19) on age (Question 6). Investigators only

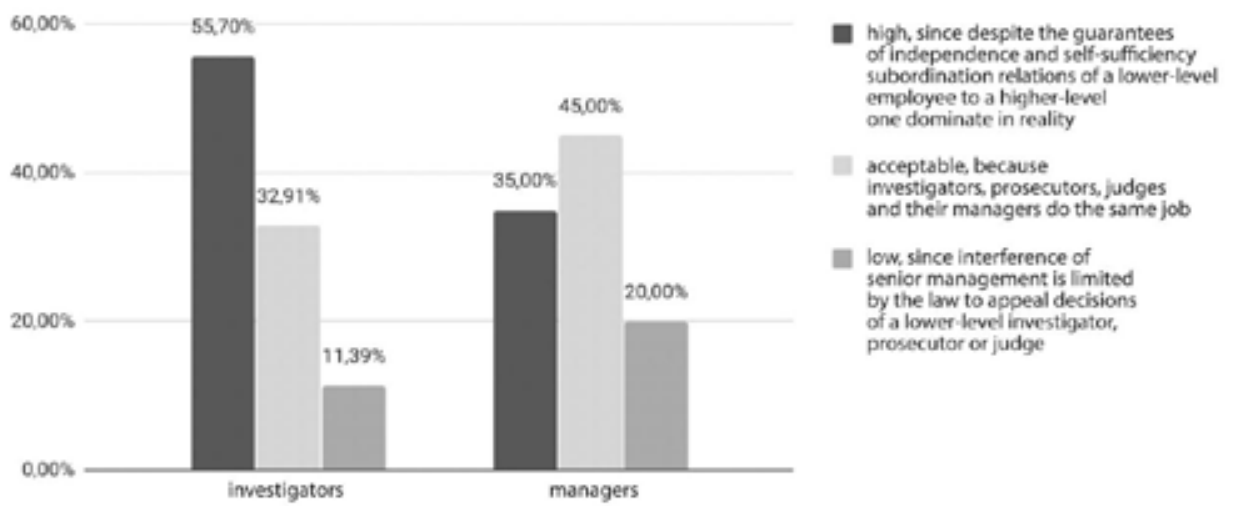

Fig. 15. The current level of managers interference in the process of investigation (Question 10) depending on position (Question 1)

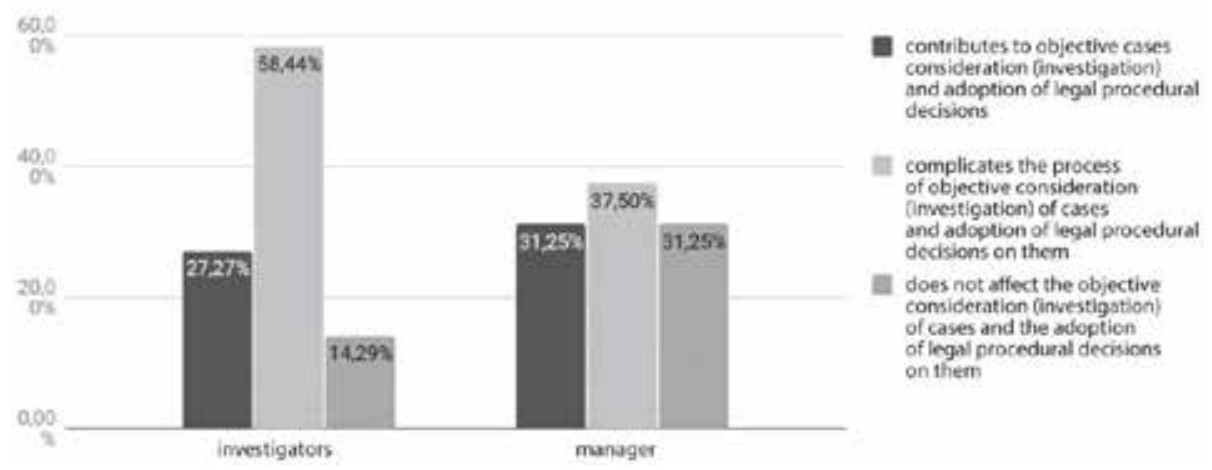

Fig. 16. The current level of investigators' dependence on senior management (Question 11) depending on position (Question 1) 
In addition to the above-mentioned critical position of investigators regarding the level of dependence on their management, it is indicative that a significant number of managers $(31.25 \%)$ note that the level of dependence does not affect the process of objective cases consideration (investigation) and adoption of procedural decisions. Thus, managers are inclined to diminish their significant influence on procedural activities of investigators, making them responsible for the result of investigation, while the study results indicate that the degree of their influence is extremely high. In this case, there is a discrepancy in the practical embodiment of the generally accepted in theory conceptual composition of investigative bodies. An investigator, according to it, is a procedurally independent and self-sufficient subject of investigation. However, in the reality of the Russian investigative system, adoption of procedural decisions by investigators largely depends on their management position. It is clearly indicated in the study. Herewith, the heads of investigative bodies often visually follow preliminary investigation order as self-sufficient and independent activity of investigators, preferring, at the same time, to retain full control over their actions, while leaving investigators responsible for the results of crimes investigation (Fig. 17).

More than a half of investigators (51.3\%) consider the level of personal discretion insufficient, as it can be levelled by the senior management position. Most managers (57.9\%) consider that their own level of discretion is sufficient, since it allows them to formulate and defend their point of view independently and sufficiently. $46.1 \%$ of investigators have the same opinion.

Along with others, the objectives of the present study are: to assess the level of judges, prosecutors and investigators' dependence on public opinion when considering (investigating) cases and making procedural decisions; establish the level of state authorities representatives' interference in the procedural activities of investigators, prosecutors and judges; to record and analyse the constructive influence of the mass media on the justice system's activities. The results obtained for these issues are presented in Fig. 18-19.

According to the aggregate estimate, the studied group mostly assesses the level of dependence as acceptable, since, due to professional reasons, the position of investigators, prosecutors and judges on some issues coin-

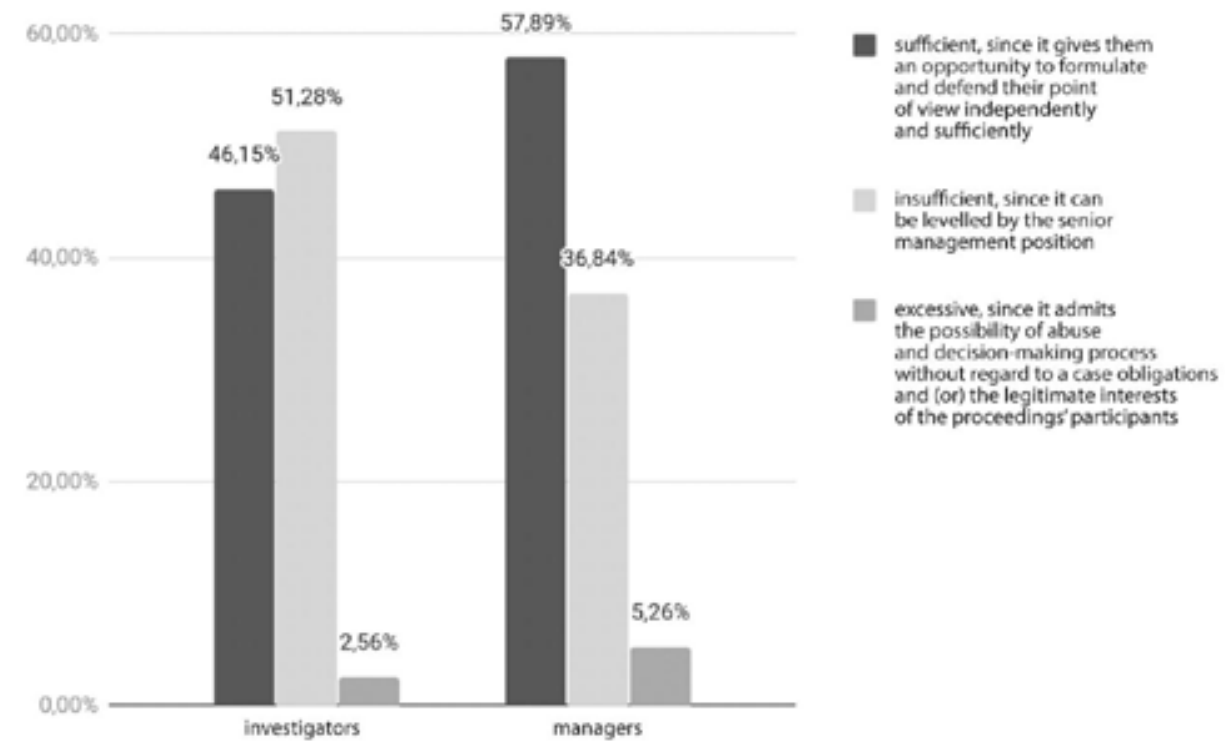

Fig. 17. Assessment of the level of personal investigators' discretion in their procedural activities (Question 17) depending on position (Question 1) 


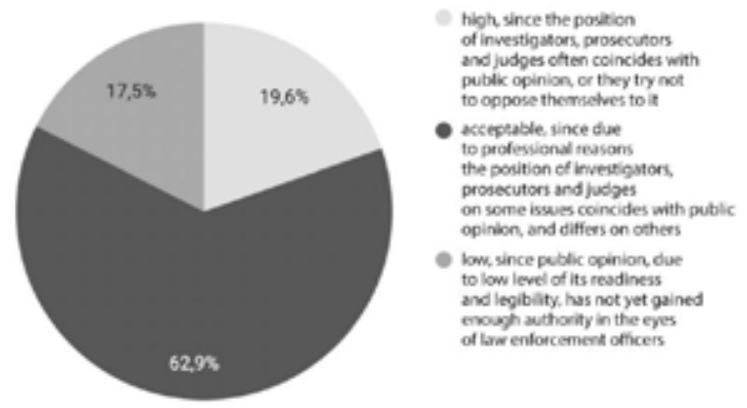

Fig. 18. The level of investigators' dependence on public opinion in the process of cases consideration (investigation) and making procedural decisions (Question 12)
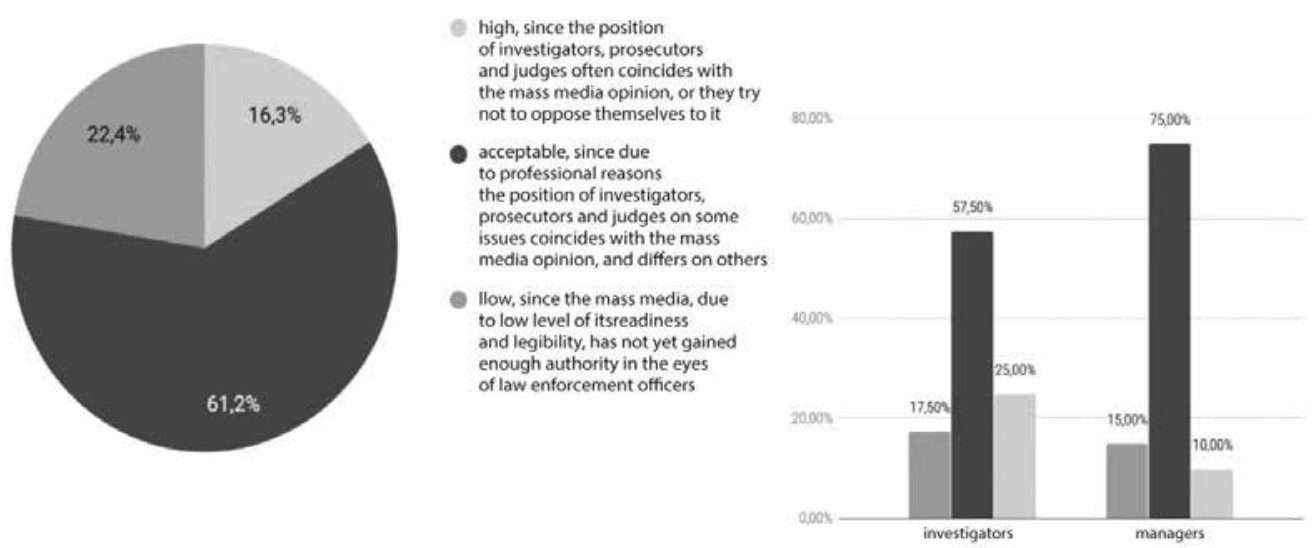

Fig. 19. The level of investigators' dependence on the mass media position when considering (investigating) cases and making procedural decisions (Question 13)

cides with public opinion and differs on others. $62.9 \%$ of the respondents note this. $19.6 \%$ believe that the level is high and about the same amount (17.5\%) assess it as low, since public opinion, due to low level of its readiness and legibility, has not yet gained enough authority in the eyes of law enforcement officers.

The results, as can be seen, are approximately similar to the previous question. Most respondents $(61.2 \%)$ consider the level of dependence on the mass media as acceptable, since, due to professional reasons, the position of investigators, prosecutors and judges on some issues coincides with the mass media opinion and differs on others. The same opinion is supported by $75 \%$ of managers and $57.5 \%$ of investigators. $22.4 \%$ of the respondents believe th at the level of dependence is low, since, due to the low level of readiness and legibility, the mass media have not yet gained enough authority in the eyes of law enforcement officers. Moreover, a quarter of the surveyed investigators and only $10 \%$ of managers have the same point of view. Thus, we can conclude that, in general, the level of the constructive mass media influence on the justice system activity is more typical for the heads of investigative bodies, $90 \%$ which speak of high and acceptable level of dependence, while for investigators this figure is $75 \%$.

\section{Conclusion}

To conclude, it can be noted that the threat to investigators' independence is mainly of an intra-systemic nature. According to the law enforcement officers, the problem lies in the justice system itself, to be more exact, in the possibility of transferring investigators admin- 
istrative subordination to their procedural dependence on their senior management's will. According to the summarised data, among other groups of law enforcement officers, the dependence is most obvious and evident for investigators. Most of them assess the level of dependence on their senior managers as high, since despite the guarantees of independence and self-sufficiency, subordination relations of a lower-level employee to a higher-level one dominate in reality (Fig. 11). This problem is particularly obvious for the most experienced investigators with more than 10 years of their length of service (Fig. 12-13), who face unacceptable interference most often (Fig. 14).

The study also revealed different perception of the problem of independence among investigators and their managers. This difference determines the study results. Within the reference group, there is a significant permanent difference between the answers of investigators and the heads of investigative bodies. Most investigators consider that the level of interference is high, while managers consider the situation to be much more favourable. Most of them indicated an acceptable level of interference (Fig. 15), and more than a half of managers note a sufficient level of personal discretion, giving investigators an opportunity to formulate and defend their point of view independently and sufficiently (Fig. 17).

Therefore, for the investigators' managers the problem under study is of local nature, since, in their opinion, investigators mainly oppose to external influence (Fig. 23, 25). Most investigators consider the level of personal discretion as insufficient, since it can be levelled by the senior management position (Fig. 17). Moreover, the problem, in their opinion, is pervasive, since it is determined by the imperfection of the justice bodies structure and organization of their activity.

The indicated difference in answers demonstrates that the problem of independence lies deep within the law enforcement system and only investigators, but not the heads of investigative bodies are concerned with it, since a third of heads indicated that the level of dependence does not affect objective cases consideration (investigation) and adoption of legal procedural decisions (Fig. 17). Moreover, the system itself does not protect the main subjects of its activity, but, on the contrary, contributes to the instability of their situation.

\section{References}

Bochkarev, S.A. (2019). Sostoianie nezavisimosti institutov pravosudiia v Rossiskoi Federatsii: sotsiologicheskoe issledovanie [State of Independence of Institutes of Justice in the Russian Federation: Sociological Research]. In Rossiskii zhurnal pravovykh issledovanii [Russian Journal of Legal Studies], 1, 9-24.

Nisnevich, Yu.A. (2019). Sudebnaia sistema postsovetskoi Rossii: sotsial'nyi kontekst [Justice System of the Post-Soviet Russia: Social Context]. In Sotsiologicheskie issledovaniia [Sociological Studies], 8, 8495.

Lapaeva, V.V. (2016). Pravo i pravovoe gosudarstvo v postsotsialisticheskoi Rossii: sostoianie i perspektivy razvitiia [Law and Rule-of-Law State in The Post-Socialist Russia: State and Development Prospects]. In Sotsiologicheskie issledovaniia [Sociological Studies], 7, 66-76.

Popova, T.V., Kalashnikova, A.S. (2018). Nauchno-prakticheskie rekomendatsii po profilaktike emotsional'nogo vygoraniia u sudei [Elektronnyi resurs] [Scientific and Practical Recommendations for The Prevention of Emotional Burnout Among Judges [Online Resource]]. In Psikhologiia i pravo [Psychology and Law], 8 (1), 119-127. DOI: 10,17759 / psylaw.2018080109.

Shadrin, V.S. (2019). Obespechenie nezavisimosti sudei kak odno iz osnovanii reformy sudebnoi sistemy [Ensuring the Independence of Judges as One of the Foundations of Judicial Reform]. In Rossiskii zhurnal pravovykh issledovanii [Russian Journal of Legal Studies], 1 (18), 32-37.

Tsvetkov, Yu.A. (2019). Nezavisimost' sudei v mekhanizme upravleniia sudebnoi sistemoi [The Independence of the Judges in the Governance of the Judicial System], In Rossiskii zhurnal pravovykh issledovanii [Russian Journal of Legal Studies], 1 (18), 73-88. 


\title{
Следствие и уровень его самостоятельности
}

\section{С.А. Бочкарев}

Институт государства и права РАН

Российская Федерация, Москва

\begin{abstract}
Аннотация. В статье приведены результаты научного исследования «Состояние отечественной системы правосудия: взгляд изнутри на ее самостоятельность и независимость», проведенного Лабораторией политико-правовых исследований факультета политологии МГУ им. М.В. Ломоносова. Изучено состояние проблемы независимости и самостоятельности в социологической группе следователей. Для выявления парных связей между ответами на вопросы анкетирования был использован статистический критерий для анализа качественных данных Хи-квадрат. Сделан вывод, что имеющиеся гарантии независимости и самостоятельности следователей не срабатывают и на деле доминируют отношения подчинения, что обусловлено существующим уровнем вмешательства вышестоящего руководителя в деятельность подчиненных сотрудников, которая отягощает процесс объективного рассмотрения (расследования) дел и принятия по ним законных процессуальных решений.

Руководители следственных органов, в отличие от следователей, в большинстве своем понимают проблему независимости и самостоятельности как противоречие внешним угрозам, поэтому в первую очередь пытаются нейтрализовать их, не обращая внимания на внутрисистемные угрозы, которые и являются основными для следователей.
\end{abstract}

Ключевые слова: следователь, руководитель следственного органа, независимость, административное воздействие, организационное устройство следственных органов.

Исследование выполнено при финансовой поддержке РФФИ в рамках научного проекта № 18-011-01232.

Научная специальность: 12.00.09 - уголовный процесс. 